\title{
Evaluation of Methionine Sources in Protein Reduced Diets for Turkeys in the Late Finishing Period Regarding Performance, Footpad Health and Liver Health
}

\author{
Jan Berend Lingens ${ }^{1, *,+}\left(\mathbb{D}\right.$, Amr Abd El-Wahab ${ }^{1,2,+}{ }^{\mathbb{C}}$, Juliano Cesar de Paula Dorigam ${ }^{3}$, Andreas Lemme ${ }^{3}(\mathbb{D}$, \\ Ralph Brehm ${ }^{4} \mathbb{(}$, Marion Langeheine ${ }^{4}(\mathbb{D})$ and Christian Visscher ${ }^{1} \mathbb{D}$ \\ 1 Institute for Animal Nutrition, University of Veterinary Medicine Hannover, Foundation, \\ Bischofsholer Damm 15, D-30173 Hannover, Germany; amrwahab5@mans.edu.eg (A.A.E.-W.); \\ christian.visscher@tiho-hannover.de (C.V.) \\ 2 Department of Nutrition and Nutritional Deficiency Diseases, Faculty of Veterinary Medicine, \\ Mansoura University, Mansoura 35516, Egypt \\ 3 Evonik Operations GmbH, Rodenbacher Chaussee 4, D-63457 Hanau, Germany; \\ juliano.dorigam@evonik.com (J.C.d.P.D.); andreas.lemme@evonik.com (A.L.) \\ 4 Institute for Anatomy, University of Veterinary Medicine Hannover, Foundation, Bischofsholer Damm 15, \\ D-30173 Hannover, Germany; ralph.brehm@tiho-hannover.de (R.B.); \\ marion.langeheine@tiho-hannover.de (M.L.) \\ * Correspondence: jan.berend.lingens@tiho-hannover.de

Citation: Lingens, J.B.; Abd El-Wahab, A.; de Paula Dorigam, J.C.; Lemme, A.; Brehm, R.; Langeheine, M.; Visscher, C. Evaluation of Methionine Sources in Protein Reduced Diets for Turkeys in the Late Finishing Period Regarding Performance, Footpad Health and Liver Health. Agriculture 2021, 11, 901 https://doi.org/10.3390/ agriculture11090901

Academic Editor: István Komlósi

Received: 13 August 2021

Accepted: 16 September 2021

Published: 19 September 2021

Publisher's Note: MDPI stays neutral with regard to jurisdictional claims in published maps and institutional affiliations.

Copyright: () 2021 by the authors. Licensee MDPI, Basel, Switzerland. This article is an open access article distributed under the terms and conditions of the Creative Commons Attribution (CC BY) license (https:// creativecommons.org/licenses/by/ $4.0 /)$.
Abstract: Footpad dermatitis and hepatic lipidosis are health problems in fattening turkeys where a positive influence of higher methionine content in feed is discussed. The effects of the methionine supplements DL-methionine (DLM) and liquid methionine hydroxyl analogue free acid (MHAFA) under the aspect of low protein diets were investigated in this study based on performance parameters, footpad health, liver health and oxidative stress. In this study, 80 female turkeys (B.U.T. Big 6) of 63 day-old, were randomly assigned to four groups characterising a $2 \times 2$ factorial design with five replicates each over five weeks. The groups were fed with diets differing in methionine source (DLM vs. MHA-FA, assuming a biological activity of MHA-FA of 65\%) and crude protein content ( $15 \%$ vs. $18 \%$ ) for 35 days. The results showed no significant interactions between the protein content and methionine source. Strong protein reduction significantly impaired water intake, feed intake, weight gain and feed conversation ratio, but improved footpad health. DLM and MHA-FA addition had no significant effect on weight gain, crude fat and protein contents in the liver, but DLM resulted in a significant increase in livers antioxidative capacity compared to MHA-FA. Although the protein reduction resulted in reduced performance, the study showed that MHA-FA can be replaced by DLM in a 100:65 weight ratio without compromising performance but with certain advantages in the antioxidative capacity of the liver.

Keywords: fattening turkey; protein; methionine; growth; hepatic lipidosis; oxidative stress

\section{Introduction}

In recent years, maintaining the competitiveness of agricultural enterprises has led to a further increase in the efficiency of animal production [1]. As a result of breeding advances, fattening turkeys with modern genetics have a high performance potential, which results in high expectations for nutrients and therefore requires better understanding of the feed composition [2]. The use of additives such as non-bound amino acids allows to adapt the diets to different feeding requirements [3]. Feed management practices, including those that substantially reduce dietary crude protein, are possibly the most important measure to reduce nitrogen excretion and the emission of nitrogen into the environment which is attained with the supplementation of non-bound amino acids $[4,5]$. 
In this context, methionine (Met) plays a central role, as it is the first limiting amino acid for poultry and serves as a building block for protein synthesis, being also a precursor for cysteine and a functional amino acid involved in methyl donation for glutathione to counter oxidative stress [4]. Basically, two products for balancing dietary methionine are commercially available: DL-methionine (DLM) and liquid methionine hydroxyl analoguefree acid (MHA-FA). Research suggests that they differ in their biological activity, which is confirmed in the assessment performed by EFSA in numerous publications as $75 \%$ on an equimolar basis [6,7]. Among other causes, a lack of methionine is discussed as a predisposing factor for footpad dermatitis (FPD), hepatic lipidosis and oxidative stress [8-11].

Various studies have shown a positive influence of Met on the footpad health of fattening turkeys $[10,12,13]$. Abd El-Wahab et al. [10] concluded that at almost identical litter dry matter (DM) contents, the FPD scores for young turkeys fed high level of Met in diet were lower than those fed dietary low Met level. It means that level of dietary Met plays an important role for health of skin rather than moisture content in the litter. Thus, it seems that Met has a specific function regards foot pad health (as known for skin and feathers) as mentioned by Abd El-Wahab et al. [14] via protein synthesis and continuous production of keratin. Furthermore, reduced protein intake also has a positive effect on footpad health by reducing excess excretion of uric acid [15]. A reduction in the protein content in feed is currently required in order to decrease the eutrophication potential of excremental ammonia as well as minimise fine dust and the nitrate intake in ground water $[5,16,17]$. Additionally, hepatic lipidosis is a metabolic disease of the liver whose pathogenesis has not been fully clarified yet, but low dietary protein and Met content as well as high starch content are discussed as predisposing factors $[9,18,19]$.

A feed composition containing minimum protein requires a higher addition of synthetic amino acids such as Met [20]. While the biological availability of MHA-FA relative to DLM has been extensively studied in broilers, less information is available for turkeys [6,21-23]. Based on their literature surveys and experiments, Hoehler and Hooge [24] and Hoehler et al. [25] recommended a bioavailability of $65 \%$ for MHA-FA relative to DLM $[25,26]$. Indeed, other research studies came to different conclusions, but this concept has successfully been applied and validated $[24,27,28]$. Therefore, in the present study, the effects of supplementation of DLM and MHA-FA in protein reduced diets were examined on growth performance, footpad health liver health and parameters of oxidative stress in late fattening female turkeys.

\section{Materials and Methods}

The experiment was carried out in accordance with German regulations. The Ethics Committee of Lower Saxony for Care and Use of Laboratory Animals (LAVES) approved the experiment in accordance with $\S 4$, paragraph 3 of the Animal Protection Act (reference number: 33.8-42502-05-18A313).

\subsection{Birds and Housing}

For the experiment, 80 female turkeys of a common fattening line were used (B.U.T. Big 6, Aviagen Turkeys Ltd., Tattenhall, UK). The birds had been grown on a commercial farm and received the Newcastle vaccine on the farm of origin. The 63 day-old turkeys were divided into four groups $(n=20)$ with five replicates. For individual identification, the turkeys were marked with coloured plastic rings on their legs. The birds were randomly allocated to 20 pens $\left(1.10 \times 2.25 \mathrm{~m}^{2}\right)$ at the beginning of the experiment (day 63) in such a manner that average body weight (BW) was similar between treatments (BW $4.03 \mathrm{~kg} / \mathrm{bird}$ ). All feeding groups were consistently distributed in the experimental rearing unit so that the pen location had no influence on the experimental results. In each pen, $5 \mathrm{~kg}$ of wood shavings (GOLDSPAN ${ }^{\circledR}$, Goldspan GmbH \& Co. KG, Goldenstedt, Germany) served as litter. The pens were equipped with drinking lines (Easy Line, LUBING Maschinenfabrik Ludwig Bening GmbH und Co. KG, Barnstorf, Germany) with two pendulum drinking 
nipples and a hanging feeder (automatic feeder, Siepmann GmbH, Herdecke, Germany). Feed and water were made available to the birds ad libitum during the trial period. The lighting programme consisted of $16 \mathrm{~h}$ light and $8 \mathrm{~h}$ darkness. The environmental temperature was controlled daily and kept at an adequate range $\left(20.0^{\circ} \mathrm{C}\right.$ and $\left.23.5^{\circ} \mathrm{C}\right)$ throughout the experimental period. At the end of the study, the turkeys were slaughtered to analyse the livers and to take footpad samples for histology.

\subsection{Feed Composition and Analysis}

In order to study the response of turkeys to the reduction in the dietary crude protein supplied with different Met sources, the diets of the four experimental groups were formulated considering these two protein contents (standard as in practice high protein $=\mathrm{HP}$ vs. low protein $=$ LP) and two Met sources (DLM vs. MHA-FA) as the main factors.

Initially, the HP diets were formulated to meet or exceed the amino acid recommendation provided for female turkeys in the breeder's guidelines [29]. Therefore Lysine sulfate and L-Threonine were added to the HP diets. To achieve a significant reduction in protein in LP diets, crystalline amino acids (L-Arginine, L-Isoleucine, L-Valine, L-Tryptophan, Lysine sulfate, L-Threonine) were supplied in order of limitation as the protein was reduced. In the formulation of the diets, it was considered either DLM (Evonik Industries AG, Essen, Germany) or MHA-FA (NOVUS Int., St. Charles, MO, USA) as the Met source and a bioavailability of MHA-FA of $65 \%$ relative to DLM was assumed considering previous results [25]. The nutritional composition of the experimental diets is shown in Table 1.

Table 1. Composition of the experimental diets.

\begin{tabular}{|c|c|c|c|c|}
\hline Ingredients (\%) & LP + DLM & LP + MHA-FA & HP + DLM & $\begin{array}{c}\text { HP + } \\
\text { MHA-FA }\end{array}$ \\
\hline Wheat & 36.0 & 36.0 & 36.0 & 36.0 \\
\hline Corn & 43.4 & 43.4 & 32.3 & 32.3 \\
\hline Soybean meal & 12.5 & 12.5 & 23.3 & 23.3 \\
\hline Soybean oil & 1.50 & 1.50 & 3.33 & 3.33 \\
\hline $\begin{array}{l}\text { Monocalcium } \\
\text { phosphate }\end{array}$ & 1.68 & 1.68 & 1.65 & 1.65 \\
\hline Calcium carbonate & 1.18 & 1.18 & 1.11 & 1.11 \\
\hline $\begin{array}{l}\text { Vitamin/mineral } \\
\text { premix }^{1}\end{array}$ & 1.00 & 1.00 & 1.00 & 1.00 \\
\hline Sodium bicarbonate & 0.26 & 0.26 & 0.26 & 0.26 \\
\hline Sodium chloride & 0.21 & 0.21 & 0.21 & 0.21 \\
\hline Lysine sulfate $(54.6 \%)$ & 0.89 & 0.89 & 0.42 & 0.42 \\
\hline MHA-FA & - & 0.46 & - & 0.32 \\
\hline DL-Methionine & 0.30 & - & 0.21 & - \\
\hline L-Threonine & 0.23 & 0.23 & 0.08 & 0.08 \\
\hline L-Arginine & 0.31 & 0.31 & - & - \\
\hline L-Isoleucine & 0.18 & 0.18 & - & - \\
\hline L-Valine & 0.17 & 0.17 & - & - \\
\hline L-Tryptophan & 0.05 & 0.05 & - & - \\
\hline \multicolumn{5}{|c|}{ 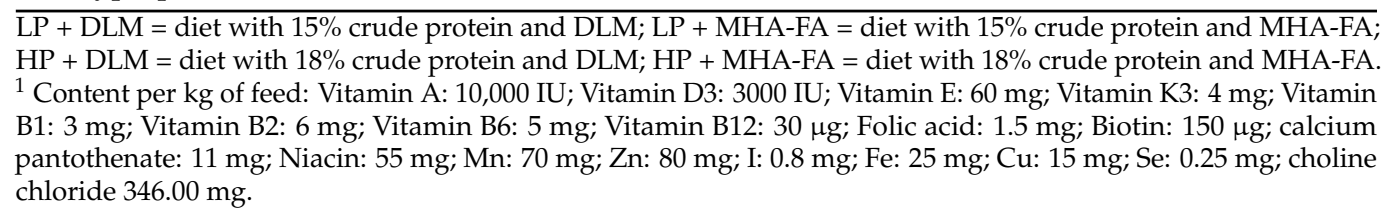 } \\
\hline
\end{tabular}

The chemical composition of the diets and Met sources (DLM) and (MHA-FA) were analysed by EVONIK Operations $\mathrm{GmbH}$, Hanau, Germany and is presented in Table 2. Dietary amino acids concentrations were determined by an Ion exchange chromatography analyzer (Biochrom 30+, Biochrom Ltd., Cambridge, UK) with post column derivatisation with ninhydrin. Amino acids were oxidised with performic acid which was neutralised with sodium metabisulfite $[30,31]$. Amino acids were liberated from the protein by hydrol- 
ysis with $6 \mathrm{~N} \mathrm{HCl}$ for $24 \mathrm{~h}$ at $110{ }^{\circ} \mathrm{C}$ and quantified with the internal standard method by measuring the absorption of reaction products with ninhydrin at $570 \mathrm{~nm}$. Supplemented amino acids were determined after extraction with $0.1 \mathrm{~N} \mathrm{HCl} \mathrm{[31].} \mathrm{Supplemented} \mathrm{MHA-FA}$ was analysed using the method described by VDLUFA [32]. Contents of ash, protein, fat, fibre, starch and sugar were analysed using near-infrared spectroscopy (Foss NIR 6500, Foss A/S, Hilleroed, Denmark).

Table 2. Calculated and analysed nutrient contents of the experimental diets.

\begin{tabular}{|c|c|c|c|c|}
\hline $\begin{array}{l}\text { Nutrient Composition } \\
\text { (g/kg, as is Basis) }\end{array}$ & LP + DLM & LP + MHA-FA & HP + DLM & $\begin{array}{c}\mathrm{HP}+ \\
\text { MHA-FA }\end{array}$ \\
\hline Crude ash & 44.0 & 43.0 & 50.0 & 51.0 \\
\hline Crude protein & 155.5 & 151.5 & 185.4 & 186.5 \\
\hline Crude fat & 37.0 & 39.0 & 55.0 & 52.0 \\
\hline Crude fibre & 23.0 & 22.0 & 25.0 & 26.0 \\
\hline Nitrogen free extract ${ }^{1}$ & 651.0 & 650.9 & 598.2 & 597.3 \\
\hline Starch & 491.0 & 485.0 & 430.0 & 420.0 \\
\hline Sugar & 26.0 & 27.0 & 38.0 & 38.0 \\
\hline SID Lysine & 10.1 & 10.1 & 10.1 & 10.1 \\
\hline SID Methionine & 4.4 & 4.4 & 4.4 & 4.4 \\
\hline $\begin{array}{l}\text { SID Methionine + } \\
\text { Cystine }\end{array}$ & 7.0 & 7.0 & 7.0 & 7.0 \\
\hline SID Threonine & 6.2 & 6.2 & 6.2 & 6.2 \\
\hline SID Valine & 7.4 & 7.4 & 7.4 & 7.4 \\
\hline SID Arginine & 10.3 & 10.3 & 10.3 & 10.3 \\
\hline Lysine & $10.8(10.7)$ & $10.8(10.8)$ & $11.1(11.3)$ & $11.1(11.0)$ \\
\hline Methionine $^{2}$ & $5.1(4.8)$ & $5.1(5.1)$ & $4.7(4.6)$ & $4.7(4.7)$ \\
\hline Methionine + Cysteine ${ }^{2}$ & $7.6(7.3)$ & $7.6(7.5)$ & $7.7(7.6)$ & $7.7(7.8)$ \\
\hline Cysteine & $2.5(2.5)$ & $2.5(2.5)$ & $3.0(3.0)$ & $3.0(3.0)$ \\
\hline Threonine & $6.9(6.9)$ & $6.9(6.6)$ & $7.2(7.3)$ & $7.2(7.2)$ \\
\hline Valine & $7.9(7.9)$ & $7.9(7.8)$ & $8.3(8.4)$ & $8.3(8.3)$ \\
\hline Arginine & $10.0(10.9)$ & $10.0(10.7)$ & $11.3(11.5)$ & $11.3(11.3)$ \\
\hline Tryptophan & $2.1(2.1)$ & $2.1(2.1)$ & $2.2(2.3)$ & $2.2(2.3)$ \\
\hline Isoleucine & $7.1(7.1)$ & $7.1(6.9)$ & $7.4(7.6)$ & $7.4(7.5)$ \\
\hline Leucine & $(11.3)$ & $(11.2)$ & $(14.3)$ & $(14.3)$ \\
\hline Histidine & $(3.40)$ & $(3.40)$ & $(4.50)$ & $(4.50)$ \\
\hline Phenylalanine & $(6.70)$ & $(6.60)$ & $(9.00)$ & $(9.00)$ \\
\hline Glycine & $(5.60)$ & $(5.50)$ & (7.40) & $(7.40)$ \\
\hline Serine & $(6.60)$ & $(6.50)$ & $(8.80)$ & $(8.90)$ \\
\hline $\begin{array}{l}\text { Metabolizable energy }{ }^{3} \\
(\mathrm{MJ} / \mathrm{kg})\end{array}$ & 12.2 & 12.1 & 12.4 & 12.2 \\
\hline \multicolumn{5}{|c|}{$\begin{array}{l}\mathrm{LP}+\mathrm{DLM}=\text { diet } \text { with } 15 \% \text { crude protein and DLM; LP + MHA-FA }=\text { diet with } 15 \% \text { crude protein and MHA-FA; } \\
\text { HP + DLM }=\text { diet with } 18 \% \text { crude protein and DLM; } \mathrm{HP}+\text { MHA-FA }=\text { diet with } 18 \% \text { crude protein and MHA-FA. } \\
{ }^{1} \text { Nitrogen-free extract }=\mathrm{DM}-\left(\text { crude ash }+ \text { crude protein }+ \text { crude fat }+ \text { crud fibre). }{ }^{2} \text { Total methionine and methio- }\right. \\
\text { nine + cysteine in the MHA-FA treatments assume } 65 \% \text { Met efficiency. }{ }^{3} \text { Metabolisable energy (per kg) }=0.01551 \\
\times \text { crude protein }+0.03431 \times \text { ether extracts }+0.01669 \times \text { starch }+0.01301 \times \text { sugar (as sucrose); } \text { SID: standardised } \\
\text { ileal digestible for total amino acids; amino acids: calculated levels (in brackets: analysed values). }\end{array}$} \\
\hline
\end{tabular}

\subsection{Parameters and Sampling Time Plan}

Individual BW, feed intake, water intake, litter DM and gross footpad scoring were measured weekly. Individual BW and weighing in and weighing out of water and feed was carried out with a calibrated scale (Sytemwaage PCE-TB30, PCE Instruments, Meschede, Germany). At the end of the trial, the birds in each group were necropsied and samples of the liver were taken to analyse crude fat, crude protein contents and total antioxidant capacity. During slaughtering, the blood samples were taken for malondialdehyde analysis and footpads were sampled for histological analysis.

\subsection{Litter Sampling}

Litter samples were taken weekly at three defined spots along a diagonal line through each box to measure the DM content. For this purpose, a cup with a diameter of $5 \mathrm{~cm}$ was 
used to punch out a sample from the full depth of the bedding as described by Ullrich et al. (2019) [33]. The three samples from each box were pooled into one pool sample and the DM content was determined on the same day.

\subsection{Gross Footpad Scoring}

The footpads of the birds were scored weekly by the same person on a scale from 0 to 7 in accordance with Mayne et al. [34]; score $0=$ healthy skin, score $7=$ more than $50 \%$ of footpad area is necrotic (Figure 1). The average scoring of both legs was performed for each bird.

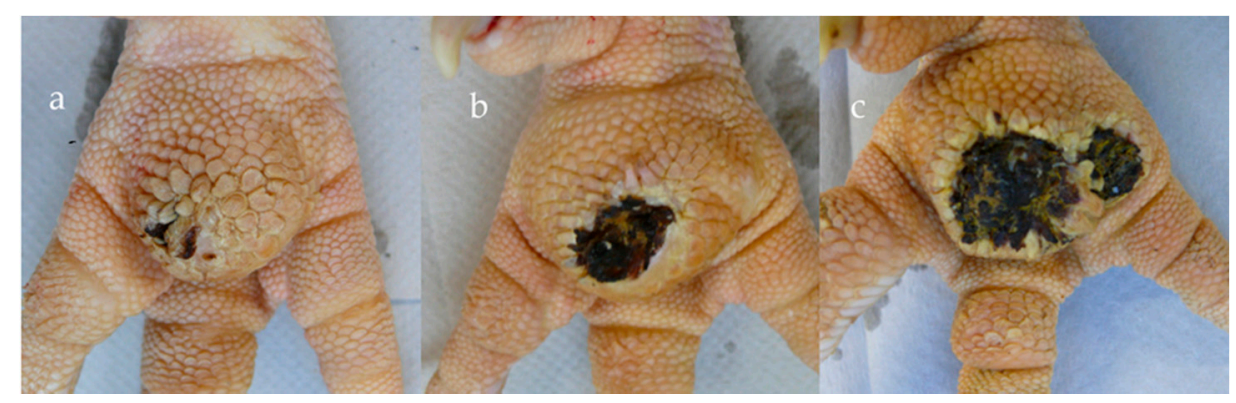

Figure 1. Scoring of foot pad: (a) Score $3=$ small necrotic areas; (b) Score $5=25 \%$ of footpad is necrotic; (c) Score $7=>50 \%$ of footpad is necrotic (photo: CAbd El-Wahab, A./University of Veterinary Medicine, Hannover, Germany).

\subsection{Histological Footpad Scoring}

In order to determine the histological footpad scoring in accordance with MAYNE et al. [34], approximately 2-cm tissue samples from footpads (middle part) were taken at dissection. The samples were first washed in phosphate-buffer saline, then fixed in $4 \%$ formaldehyde for $48 \mathrm{~h}$. After fixation, the samples were embedded in paraffin and $4-\mu \mathrm{m}$ sections of all samples were stained with haematoxylin and eosin using standard techniques. The sections were examined under a light microscope and categorised using the histopathological scoring system on a 7-point scale $(0=$ normal epidermis; $1=$ hyperkeratosis; 2 = epidermal acanthosis; $3=$ vacuoles in dermis and epidermis; $4=$ presence of heterophils, macrophages and lymphocytes in dermis; $5=$ increased density of heterophils, macrophages and lymphocytes; $6=$ ulcer of the epidermis, only one lesion; $7=$ more than one rupture or "ulcer" of the epidermis) in accordance with Mayne et al. [34].

\subsection{Analysis of Liver Samples}

The livers were first processed in accordance with the method described by Middendorf et al. (2019) for further chemical analysis [35]. The livers were first homogenised in a mixer (Grindomix GM 200, Retsch GmbH, Haan, Germany) and then freeze-dried (freeze dryer Gamma 1-20, Martin Christ Gefriertrocknungsanlagen GmbH, Osterode am Harz, Germany). The freeze-dried material was grinded in a mill (M20 universal mixer, IKA Werke GmbH und Co. KG, Staufen, Germany). The levels of DM and alpha-tocopherol determination were performed with the homogenised livers, whereas the crude fat and crude protein analyses were performed with the freeze-dried and grinded materials. The levels of liver DM, alpha-tocopherol, crude protein and crude fat were determined using the VDLUFA methods in accordance with Naumann and Bassler [36].

\subsection{Oxidative Stress}

Total antioxidant capacity (TAC) of liver parenchyma was determined in accordance with SHEN et al. [11]. Briefly, the TAC was determined by ELISA (ELISA Kit OxiSelect ${ }^{\mathrm{TM}}$ Total Antioxidant Capacity Assay Kit, Fa. Cell Biolabs, Inc., San Diego, CA, USA). Using the ELISA Kit, the TAC was calculated in relation to the liver protein. Malondialdehyde was determined in blood plasma of ten animals per group after dissection. This was performed 
by SYNLAB (Medizinisches Versorgungszentrum Labor München Zentrum GbR München, Germany) in accordance with the method by Chromsystems Instruments and Chemicals $\mathrm{GmbH}$, Gräfelfing, Germany using the HPLC test kit "Malondialdehyde in Serum/Plasma HPLC" (Chromsystems Instruments and Chemicals GmbH, Gräfelfing, Germany).

\subsection{Statistical Analysis}

The statistical evaluation was carried out with the program SAS (Statistical Analysis System) Enterprise Guide 7.1 (SAS Institute Inc., Cary, NC, USA) in cooperation with the Institute for Biometry, Epidemiology and Information Processing of the University of Veterinary Medicine Hannover, Foundation, Germany. The sample size was calculated assuming an effect size of 0.25 for the main effect (footpad health), the alpha was set to 0.05 and the power to 0.60 . With a numerator of the degrees of freedom (df) of 1 and 4 groups 81 animals were necessary. A Shapiro-Wilk test for normal distribution was performed and normally distributed data were checked for significant differences with the Ryan-Einot-Gabriel-Welsch-test (one-way ANOVA). For not normally distributed data, a Kruskal Wallis test was performed, followed by a Wilcoxon two-sample test. Histological and macroscopical foot pad scoring were performed using a Kruskal Wallis test. The significance level was set at $p<0.05$.

\section{Results}

All birds were healthy and there were no mortalities during the experimental period. Additionally, there were no complications and no animals had to be medically treated during the experiment.

\subsection{Performance}

The results of the weekly BW recording are presented in Table 3. The BW was in accordance with the performance goals for B.U.T. Big 6 heavy lines [37].

Table 3. Average body weight (BW) of female turkeys fed experimental diets with different dietary protein content and using different methionine sources (DL-Methionine-DLM; liquid methionine hydroxyl analogue-free acid-MHA-FA) from day 63 to $98(\mathrm{~kg} / \mathrm{bird}$, mean $+/-\mathrm{SD})$.

\begin{tabular}{|c|c|c|c|c|c|c|c|}
\hline \multirow{2}{*}{$\begin{array}{l}\text { Protein } \\
\text { Content }\end{array}$} & \multirow{2}{*}{$\begin{array}{c}\text { Methionine } \\
\text { Source }\end{array}$} & \multicolumn{6}{|c|}{ Experimental Period } \\
\hline & & Day 63 & Day 70 & Day 77 & Day 84 & Day 91 & Day 98 \\
\hline Low $^{1}$ & DLM & $4.05 \pm 0.37$ & $4.87 \pm 0.50$ & $5.73 \pm 0.58$ & $6.69^{a b} \pm 0.63$ & $7.69^{a b} \pm 0.72$ & $8.56^{b c} \pm 0.74$ \\
\hline Low $^{1}$ & MHA-FA & $4.01 \pm 0.32$ & $4.76 \pm 0.38$ & $5.66 \pm 0.42$ & $6.50^{b} \pm 0.47$ & $7.43^{b} \pm 0.57$ & $8.27^{\mathrm{c}} \pm 0.64$ \\
\hline High $^{2}$ & DLM & $4.07 \pm 0.30$ & $5.08 \pm 0.35$ & $6.04 \pm 0.40$ & $7.06^{\mathrm{a}} \pm 0.48$ & $8.15^{a} \pm 0.49$ & $9.06^{\mathrm{a}} \pm 0.57$ \\
\hline High $^{2}$ & MHA-FA & $3.99 \pm 0.43$ & $4.91 \pm 0.45$ & $5.88 \pm 0.57$ & $6.89^{\mathrm{ab}} \pm 0.60$ & $7.95^{\mathrm{a}} \pm 0.64$ & $8.85^{\mathrm{ab}} \pm 0.63$ \\
\hline \multicolumn{2}{|c|}{ Factor } & \multicolumn{6}{|c|}{$p$-value } \\
\hline Protei & ntent (A) & 0.9652 & 0.0628 & 0.0193 & 0.003 & 0.0006 & 0.0004 \\
\hline Methior & source (B) & 0.4672 & 0.1461 & 0.2994 & 0.1419 & 0.1033 & 0.0889 \\
\hline \multicolumn{2}{|c|}{$\mathrm{A} \times \mathrm{B}$} & 0.8034 & 0.7658 & 0.7074 & 0.9563 & 0.8039 & 0.7956 \\
\hline & & \multicolumn{6}{|c|}{ Main effects } \\
\hline \multicolumn{2}{|c|}{ Low protein content } & $4.03 \pm 0.34$ & $4.81 \pm 0.45$ & $5.69^{b} \pm 0.50$ & $6.60^{b} \pm 0.56$ & $7.56^{b} \pm 0.65$ & $8.41^{b} \pm 0.70$ \\
\hline \multirow{2}{*}{\multicolumn{2}{|c|}{$\begin{array}{l}\text { High protein content } \\
\text { DLM source }\end{array}$}} & $4.03 \pm 0.37$ & $4.99 \pm 0.41$ & $5.96^{\mathrm{a}} \pm 0.49$ & $6.97^{\mathrm{a}} \pm 0.54$ & $8.05^{a} \pm 0.57$ & $8.95^{\mathrm{a}} \pm 0.60$ \\
\hline & & $4.06 \pm 0.33$ & $4.97 \pm 0.44$ & $5.88 \pm 0.51$ & $6.88 \pm 0.58$ & $7.92 \pm 0.65$ & $8.81 \pm 0.70$ \\
\hline \multicolumn{2}{|c|}{ MHA-FA source } & $4.00 \pm 0.37$ & $4.83 \pm 0.42$ & $5.77 \pm 0.51$ & $6.70 \pm 0.57$ & $7.69 \pm 0.66$ & $8.56 \pm 0.69$ \\
\hline
\end{tabular}

a,b,c Means in a column within each main effects with different superscripts differ significantly $(p<0.05) ;{ }^{1}$ diet with $15 \%$ crude protein;

2 diet with $18 \%$ crude protein.

No interactions were observed between the crude protein level and methionine source $(p>0.05)$. Therefore, the responses of methionine sources and protein levels were independent and the main factors were analysed. There was no significant difference between the methionine sources $(p>0.05)$, but the groups fed DLM showed a tendency $(p=0.0889)$ for a higher final BW compared to MHA-FA. From the second week of the experiment onwards, 
protein reduction led to a significantly lower BW $(p<0.05)$. The performance data obtained in the 35-day period for feed intake, water intake, water to feed intake ratio (W:F), BW gain, protein efficiency ratio (PER) and feed conversation ratio (FCR) are presented in Table 4.

Table 4. Feed intake (FI), water intake (WI), water to feed ratio (W:F), body weight gain (BW), protein efficiency ratio (PER) and feed conversion ratio (FCR) of female turkeys fed experimental diets with different dietary protein content and using different methionine sources (DL-Methionine-DLM; liquid methionine hydroxyl analogue-free acid-MHA-FA) from day 63 to 98 (mean $\pm \mathrm{SD}$ ).

\begin{tabular}{|c|c|c|c|c|c|c|c|}
\hline \multirow{2}{*}{$\begin{array}{l}\text { Protein } \\
\text { Content }\end{array}$} & \multirow{2}{*}{$\begin{array}{c}\text { Methionine } \\
\text { Source }\end{array}$} & \multicolumn{6}{|c|}{ Performance Parameters } \\
\hline & & FI (g) & WI (g) & $\begin{array}{c}\text { W:F Intake } \\
\text { (g/g) }\end{array}$ & BW Gain (g) & PER (g/g) & FCR $(\mathrm{kg} / \mathrm{kg})$ \\
\hline Low $^{1}$ & DLM & $12,532^{\mathrm{ab}} \pm 388$ & $\begin{array}{c}23,862^{b c} \\
1278\end{array}$ & $1.90^{\mathrm{b}} \pm 0.07$ & $4505^{b} \pm 460$ & $2.30^{a} \pm 0.05$ & $2.78^{a} \pm 0.05$ \\
\hline Low $^{1}$ & MHA-FA & $11,868^{\mathrm{b}} \pm 485$ & $22,623^{c} \pm 1025$ & $1.91^{\mathrm{b}} \pm 0.06$ & $4255^{\mathrm{b}} \pm 543$ & $2.31^{\mathrm{a}} \pm 0.05$ & $2.79^{a} \pm 0.06$ \\
\hline High $^{2}$ & DLM & $13,006^{\mathrm{a}} \pm 411$ & $26,464^{a} \pm 735$ & $2.04^{\mathrm{a}} \pm 0.03$ & $4991^{\mathrm{a}} \pm 445$ & $2.08^{b} \pm 0.04$ & $2.61^{b} \pm 0.05$ \\
\hline High $^{2}$ & MHA-FA & $12,589^{a} \pm 453$ & $25,428^{a b} \pm 999$ & $2.02^{\mathrm{a}} \pm 0.05$ & $4857^{\mathrm{a}} \pm 450$ & $2.06^{b} \pm 0.06$ & $2.60^{b} \pm 0.07$ \\
\hline \multicolumn{2}{|c|}{ Factor } & \multicolumn{6}{|c|}{$p$-value } \\
\hline Protein & ntent (A) & 0.0075 & $<0.0001$ & 0.0001 & $<0.0001$ & $<0.0001$ & $<0.0001$ \\
\hline Methion & source (B) & 0.0137 & 0.0248 & 0.8061 & 0.0759 & 0.9002 & 0.966 \\
\hline \multicolumn{2}{|c|}{$\mathrm{A} \times \mathrm{B}$} & 0.5339 & 0.828 & 0.7063 & 0.5894 & 0.4755 & 0.7177 \\
\hline & & \multicolumn{6}{|c|}{ Main effects } \\
\hline \multicolumn{2}{|c|}{ Low protein content } & $12,200^{b} \pm 543$ & $23,243^{b} \pm 1272$ & $1.91^{\mathrm{b}} \pm 0.06$ & $4380^{b} \pm 513$ & $2.30^{\mathrm{a}} \pm 0.05$ & $2.79^{\mathrm{a}} \pm 0.06$ \\
\hline \multicolumn{2}{|c|}{ High protein content } & $12,797^{\mathrm{a}} \pm 463$ & $25,946^{\mathrm{a}} \pm 991$ & $2.03^{\mathrm{a}} \pm 0.04$ & $4924^{\mathrm{a}} \pm 447$ & $2.07^{b} \pm 0.05$ & $2.60^{b} \pm 0.06$ \\
\hline \multicolumn{2}{|c|}{ DLM source } & $12,769^{a} \pm 452$ & $25,163^{a} \pm 1687$ & $1.97 \pm 0.08$ & $4748 \pm 510$ & $2.19 \pm 0.12$ & $2.69 \pm 0.11$ \\
\hline \multicolumn{2}{|c|}{ MHA-FA source } & $12,229^{b} \pm 583$ & $24,026^{b} \pm 1759$ & $1.96 \pm 0.08$ & $4556 \pm 579$ & $2.18 \pm 0.14$ & $2.69 \pm 0.12$ \\
\hline
\end{tabular}

a,b,c Means in a column within each main effects with different superscripts differ significantly $(p<0.05){ }^{1}$ diet with $15 \%$ crude protein;

2 diet with $18 \%$ crude protein.

No interactions were observed between the dietary protein level and Met source $(p>0.05)$ for the performance parameters in the entire period. The analysis of the main factors showed that birds fed diets with MHA-FA had a significantly lower feed intake and water intake compared to the birds fed DLM. The groups fed DLM showed a tendency $(p=0.0759)$ for a higher BW gain compared to MHA-FA. Independent of the evaluated Met source, the protein reduction led to a significantly lower feed intake, water intake, W:F intake ratio, BW gain and a higher PER and FCR $(p<0.05)$.

\subsection{Litter Quality and Footpad Dermatitis}

The results of the DM content of the litter material measured weekly are presented in Table 5.

As shown in Table 5, there were no interactions between the crude protein level and methionine source $(p>0.05)$ for dry matter content of the litter material during the trial, neither for the crude protein level effect $(p>0.05)$ nor methionine source effect $(p>0.05)$ when the main factors were taken into consideration for the statistical analysis. The results for FPD scores are presented in Table 6. 
Table 5. Dry matter content (\%) of the litter of female turkeys fed experimental diets with different dietary protein content and using different methionine sources (DL-Methionine-DLM; liquid methionine hydroxyl analogue-free acid-MHA-FA) from day 70 to 98 (mean $\pm \mathrm{SD}$ ).

\begin{tabular}{|c|c|c|c|c|c|c|}
\hline \multirow{2}{*}{$\begin{array}{l}\text { Protein } \\
\text { Content }\end{array}$} & \multirow{2}{*}{$\begin{array}{l}\text { Methionine } \\
\text { Source }\end{array}$} & \multicolumn{5}{|c|}{ Experimental Period } \\
\hline & & Day 70 & Day 77 & Day 84 & Day 91 & Day 98 \\
\hline Low $^{1}$ & DLM & $49.6 \pm 8.46$ & $58.1 \pm 4.47$ & $65.3 \pm 6.60$ & $65.5 \pm 7.81$ & $64.6 \pm 7.16$ \\
\hline Low $^{1}$ & MHA-FA & $48.3 \pm 6.48$ & $52.3 \pm 7.05$ & $62.4 \pm 5.05$ & $62.3 \pm 7.16$ & $62.0 \pm 3.98$ \\
\hline High $^{2}$ & DLM & $48.8 \pm 6.20$ & $57.1 \pm 4.90$ & $58.5 \pm 4.71$ & $58.6 \pm 5.07$ & $59.7 \pm 5.10$ \\
\hline High $^{2}$ & MHA-FA & $54.1 \pm 6.37$ & $59.3 \pm 9.23$ & $66.0 \pm 6.60$ & $59.5 \pm 5.58$ & $66.5 \pm 3.82$ \\
\hline \multicolumn{2}{|c|}{ Factor } & & & $p$-value & & \\
\hline \multicolumn{2}{|c|}{ Protein content (A) } & 0.4503 & 0.3899 & 0.5865 & 0.1519 & 0.9371 \\
\hline \multicolumn{2}{|c|}{ Methionine source (B) } & 0.5494 & 0.5956 & 0.4395 & 0.7312 & 0.4303 \\
\hline \multicolumn{2}{|c|}{$\mathrm{A} \times \mathrm{B}$} & 0.3207 & 0.2488 & 0.0911 & 0.5293 & 0.0903 \\
\hline \multicolumn{2}{|c|}{ Low protein content } & $48.9 \pm 7.97$ & $55.2 \pm 6.93$ & $\begin{array}{c}\text { Main effects } \\
63.8 \pm 6.38\end{array}$ & $63.9 \pm 8.08$ & $63.3 \pm 6.26$ \\
\hline \multicolumn{2}{|c|}{ High protein content } & $51.4 \pm 5.99$ & $58.2 \pm 7.87$ & $62.2 \pm 7.23$ & $59.0 \pm 5.64$ & $63.1 \pm 5.94$ \\
\hline \multicolumn{2}{|c|}{ DLM source } & $49.2 \pm 6.76$ & $57.6 \pm 4.97$ & $61.9 \pm 7.03$ & $62.0 \pm 7.85$ & $62.2 \pm 7.04$ \\
\hline \multicolumn{2}{|c|}{ MHA-FA source } & $51.2 \pm 7.42$ & $55.8 \pm 9.40$ & $64.2 \pm 6.48$ & $60.9 \pm 6.92$ & $64.3 \pm 4.74$ \\
\hline
\end{tabular}

${ }^{1}$ diet with $15 \%$ crude protein; ${ }^{2}$ diet with $18 \%$ crude protein.

Table 6. Gross lesions of FPD of female turkeys fed experimental diets with different dietary protein content and using different methionine sources (DL-Methionine-DLM; liquid methionine hydroxyl analogue-free acid-MHA-FA) from day 63 to 98 (mean \pm SD).

\begin{tabular}{|c|c|c|c|c|c|c|c|}
\hline \multirow{2}{*}{$\begin{array}{l}\text { Protein } \\
\text { Content }\end{array}$} & \multirow{2}{*}{$\begin{array}{l}\text { Methionine } \\
\text { Source }\end{array}$} & \multicolumn{6}{|c|}{ Experimental Period } \\
\hline & & Day 63 & Day 70 & Day 77 & Day 84 & Day 91 & Day 98 \\
\hline Low ${ }^{1}$ & DLM & $3.90 \pm 0.55$ & $3.98 \pm 0.60$ & $2.90 \pm 0.55$ & $2.35 \pm 0.67$ & $1.98 \pm 0.44$ & $1.38^{\mathrm{c}} \pm 0.65$ \\
\hline Low $^{1}$ & MHA-FA & $4.00 \pm 0.51$ & $4.03 \pm 0.62$ & $2.83 \pm 0.67$ & $2.28 \pm 0.55$ & $1.83 \pm 0.47$ & $1.80^{\mathrm{bc}} \pm 0.71$ \\
\hline High $^{2}$ & DLM & $3.90 \pm 0.58$ & $3.88 \pm 0.56$ & $2.63 \pm 0.46$ & $2.33 \pm 0.80$ & $2.25 \pm 0.79$ & $2.18^{\mathrm{ab}} \pm 0.65$ \\
\hline High $^{2}$ & MHA-FA & $4.10 \pm 0.55$ & $3.95 \pm 0.48$ & $2.70 \pm 0.57$ & $2.43 \pm 0.57$ & $2.28 \pm 0.55$ & $2.38^{a} \pm 0.51$ \\
\hline \multicolumn{2}{|c|}{ Factor } & \multicolumn{6}{|c|}{$p$-value } \\
\hline Protei & tent (A) & 0.8767 & 0.5453 & 0.0885 & 0.8039 & 0.0099 & 0.0001 \\
\hline \multirow{2}{*}{\multicolumn{2}{|c|}{ Methionine source (B) }} & 0.3071 & 0.3306 & 0.9920 & 0.6195 & 0.7590 & 0.0580 \\
\hline & & \multicolumn{6}{|c|}{ Main effects } \\
\hline \multicolumn{2}{|c|}{ Low protein content } & $3.95 \pm 0.53$ & $4.00 \pm 0.60$ & $2.86^{\mathrm{a}} \pm 0.61$ & $2.31^{b} \pm 0.61$ & $1.90^{b} \pm 0.46$ & $1.59^{b} \pm 0.71$ \\
\hline \multicolumn{2}{|c|}{ High protein content } & $4.00 \pm 0.57$ & $3.91 \pm 0.52$ & $2.66^{\mathrm{b}} \pm 0.51$ & $2.38^{a} \pm 0.69$ & $2.26^{\mathrm{a}} \pm 0.67$ & $2.28^{a} \pm 0.59$ \\
\hline \multicolumn{2}{|c|}{ DLM source } & $3.90 \pm 0.56$ & $3.93 \pm 0.57$ & $2.76 \pm 0.52$ & $2.34 \pm 0.73$ & $2.11 \pm 0.65$ & $1.78 \pm 0.76$ \\
\hline \multicolumn{2}{|c|}{ MHA-FA source } & $4.05 \pm 0.53$ & $3.99 \pm 0.55$ & $2.76 \pm 0.62$ & $2.35 \pm 0.56$ & $2.05 \pm 0.55$ & $2.09 \pm 0.68$ \\
\hline
\end{tabular}

$\mathrm{a}, \mathrm{b}, \mathrm{c}$ Means in a column within each main effects with different superscripts differ significantly $(p<0.05) .{ }^{1}$ diet with $15 \%$ crude protein;

2 diet with $18 \%$ crude protein.

As shown in Table 6, footpad health scores reduced during the course of the experiment from about 4.0 at day 63 to about 1.9 at day 98 . An evaluation according to the factor protein level showed a significant effect on footpad health. While, there were no significant protein effects from day 63 to day 84 , protein reduction resulted in a significant impairment of the footpad score at day 91 and day $98(p<0.05)$. The evaluation according to the factor Met source showed a tendency $(p<0.10)$ to lower footpad scores for the DLM diets compared to MHA-FA on the last day of the experiment.

As shown in Table 7, an evaluation according to the factor protein level showed a significant improvement in the histological footpad score for low protein diets, while the evaluation according to the factor Met source showed no effect of the Met source on the histological footpad score. 
Table 7. Histological FPD scores of female turkeys fed experimental diets with different dietary protein content and using different methionine sources (DL-Methionine-DLM; liquid methionine hydroxyl analogue-free acid-MHA-FA) (mean $\pm \mathrm{SD}$ ).

\begin{tabular}{|c|c|c|}
\hline Protein Content & Methionine Source & Day 98 of Life \\
\hline Low $^{1}$ & DLM & $2.25^{\mathrm{b}} \pm 1.02$ \\
\hline Low $^{1}$ & MHA-FA & $2.75^{\mathrm{ab}} \pm 1.07$ \\
\hline High $^{2}$ & DLM & $3.20^{\mathrm{a}} \pm 0.89$ \\
\hline High $^{2}$ & MHA-FA & $3.25^{\mathrm{a}} \pm 0.72$ \\
\hline \multicolumn{2}{|c|}{ Factor } & $p$-value \\
\hline \multicolumn{2}{|c|}{ Protein content (A) } & 0.0016 \\
\hline \multirow{2}{*}{\multicolumn{2}{|c|}{ Methionine source (B) }} & 0.1733 \\
\hline & & Main effects \\
\hline \multicolumn{2}{|c|}{ Low protein content } & $2.50^{b} \pm 1.06$ \\
\hline \multicolumn{2}{|c|}{ High protein content } & $3.23^{\mathrm{a}} \pm 0.80$ \\
\hline \multicolumn{2}{|c|}{ DLM source } & $2.73 \pm 1.06$ \\
\hline \multicolumn{2}{|c|}{ MHA-FA source } & $3.00 \pm 0.93$ \\
\hline
\end{tabular}

$\overline{\mathrm{a}, \mathrm{b}}$ Means in a column within each main effects with different superscripts differ significantly $(p<0.05) .{ }^{1}$ diet with $15 \%$ crude protein; ${ }^{2}$ diet with $18 \%$ crude protein.

\subsection{Liver Parameters}

The absolute liver weight and relative liver weight, DM content, fat and protein contents of liver (mean \pm SD) are presented in Table 8. With the exception of relative liver weight, there was no significant impact by the dietary protein level or Met source nor were there any interactions. The experiment showed a significantly increased relative liver weight due to the protein reduced diets $(p<0.05)$. DLM and MHA-FA nutrition had no significant effect on liver weight gain or fat and protein contents in livers.

Table 8. Absolute and relative liver weights as well as the contents of DM, fat and protein in the liver of female turkeys fed experimental diets with different dietary protein content and using different methionine sources (DL-Methionine-DLM; liquid methionine hydroxyl analogue-free acidMHA-FA) at day 98 (mean $\pm \mathrm{SD}$ ).

\begin{tabular}{|c|c|c|c|c|c|c|}
\hline \multirow[b]{2}{*}{$\begin{array}{l}\text { Protein } \\
\text { Content }\end{array}$} & \multirow[b]{2}{*}{$\begin{array}{c}\text { Methionine } \\
\text { Source }\end{array}$} & \multicolumn{5}{|c|}{ Item } \\
\hline & & $\begin{array}{c}\text { Absolute } \\
\text { Weight (g) }\end{array}$ & $\begin{array}{c}\text { Relative } \\
\text { Weight (\%) }\end{array}$ & DM (g/kg) & $\begin{array}{c}\text { Fibre } \\
\text { (g/kg DM) }\end{array}$ & $\begin{array}{c}\text { Protein } \\
\text { (g/kg DM) }\end{array}$ \\
\hline Low $^{1}$ & DLM & $147 \pm 23.6$ & $1.71 \pm 0.23$ & $304 \pm 16.3$ & $157 \pm 49.7$ & $620 \pm 62.5$ \\
\hline Low $^{1}$ & MHA-FA & $140 \pm 28.5$ & $1.68 \pm 0.29$ & $300 \pm 18.6$ & $144 \pm 49.9$ & $621 \pm 71.0$ \\
\hline High $^{2}$ & DLM & $142 \pm 20.7$ & $1.57 \pm 0.18$ & $303 \pm 13.4$ & $143 \pm 40.2$ & $633 \pm 48.8$ \\
\hline \multicolumn{2}{|c|}{ Factor } & $136 \pm 22.9$ & $1.54 \pm 0.21$ & $\begin{array}{c}301 \pm 12.2 \\
p \text {-value }\end{array}$ & $132 \pm 33.2$ & $639 \pm 44.4$ \\
\hline Protein & content (A) & 0.4793 & 0.0064 & 0.9074 & 0.1785 & 0.2239 \\
\hline Methion & he source (B) & 0.2461 & 0.5821 & 0.3611 & 0.2064 & 0.7842 \\
\hline \multicolumn{2}{|c|}{$\mathrm{A} \times \mathrm{B}$} & 0.9195 & 0.9952 & $\begin{array}{c}0.7713 \\
\text { Main effects }\end{array}$ & 0.907 & 0.8309 \\
\hline Low pr & tein content & $143 \pm 26.1$ & $1.70^{\mathrm{a}} \pm 0.26$ & $302 \pm 17.4$ & $151 \pm 49.7$ & $620 \pm 66.0$ \\
\hline High pr & tein content & $139 \pm 21.7$ & $1.55^{b} \pm 0.19$ & $302 \pm 12.7$ & $137 \pm 36.8$ & $636 \pm 46.2$ \\
\hline DLI & I source & $144 \pm 22.0$ & $1.64 \pm 0.22$ & $303 \pm 14.7$ & $150 \pm 45.2$ & $626 \pm 55.7$ \\
\hline MHA & FA source & $138 \pm 25.6$ & $1.61 \pm 0.26$ & $300 \pm 15.5$ & $138 \pm 42.3$ & $630 \pm 59.2$ \\
\hline
\end{tabular}

$\overline{\mathrm{a}, \mathrm{b}}$ Means in a column within each main effects with different superscripts differ significantly $(p<0.05) .{ }^{1}$ diet with $15 \%$ crude protein; ${ }^{2}$ diet with $18 \%$ crude protein.

\subsection{Parameter of Oxidative Stress}

The content of vitamin E and total antioxidant capacity (TAC) of the liver, as well as the malondialdehyde in blood plasma values are presented in Table 9. No interactions of main factors were found. Also, the dietary protein level did not affect either listed parameter. 
The two-factorial ANOVA showed a significant increase in TAC of the liver parenchyma for DLM compared to MHA-FA ( $p<0.05 ; 1.05$ vs. $0.96 \mu \mathrm{mol} \mathrm{UAE/g} \mathrm{liver} \mathrm{protein).}$

Table 9. Content of Vitamin E and total antioxidant capacity (TAC) of the liver, malondialdehyde in blood plasma used as an indicator of oxidative stress of female turkeys fed experimental diets with different dietary protein content and using different methionine sources (DL-Methionine-DLM; liquid methionine hydroxyl analogue-free acid-MHA-FA) at day 98 (mean \pm SD).

\begin{tabular}{|c|c|c|c|c|}
\hline \multirow[b]{2}{*}{$\begin{array}{l}\text { Protein } \\
\text { Content }\end{array}$} & \multirow[b]{2}{*}{$\begin{array}{c}\text { Methionine } \\
\text { Source }\end{array}$} & \multicolumn{3}{|c|}{ Oxidative Stress Parameter } \\
\hline & & $\begin{array}{c}\text { Viamin E } \\
(\mathrm{mg} / \mathrm{kg} \mathrm{DM})\end{array}$ & $\begin{array}{c}\text { TAC ( } \mu \text { mol } \\
\text { UAE/g } \\
\text { Protein) }\end{array}$ & $\begin{array}{l}\text { Malondialdehyde } \\
\text { ( } \mu \mathrm{mol} / \text { Liter })\end{array}$ \\
\hline Low $^{1}$ & DLM & $16.2 \pm 6.56$ & $1.02^{\mathrm{ab}} \pm 0.20$ & $0.38 \pm 0.11$ \\
\hline Low $^{1}$ & MHA-FA & $15.8 \pm 5.52$ & $0.93^{b} \pm 0.11$ & $0.34 \pm 0.10$ \\
\hline High $^{2}$ & DLM & $14.0 \pm 4.57$ & $1.08^{\mathrm{a}} \pm 0.17$ & $0.36 \pm 0.09$ \\
\hline High $^{2}$ & MHA-FA & $15.5 \pm 4.65$ & $1.00^{\mathrm{ab}} \pm 0.17$ & $0.38 \pm 0.10$ \\
\hline \multicolumn{2}{|c|}{ Factor } & \multicolumn{3}{|c|}{$p$-value } \\
\hline Prot & tent $(\mathrm{A})$ & 0.2950 & 0.1086 & 0.8367 \\
\hline Methi & ource (B) & 0.6471 & 0.0260 & 0.7633 \\
\hline \multirow{2}{*}{\multicolumn{2}{|c|}{$\mathrm{A} \times \mathrm{B}$}} & 0.4238 & 0.8563 & 0.3856 \\
\hline & & \multicolumn{3}{|c|}{ Main effects } \\
\hline Low & content & $16.0 \pm 5.99$ & $0.98 \pm 0.17$ & $0.36 \pm 0.10$ \\
\hline High & content & $14.8 \pm 4.62$ & $1.04 \pm 0.17$ & $0.37 \pm 0.09$ \\
\hline & urce & $15.1 \pm 5.70$ & $1.05^{\mathrm{a}} \pm 0.19$ & $0.37 \pm 0.10$ \\
\hline $\mathrm{MH}$ & source & $15.7 \pm 5.04$ & $0.96^{\mathrm{b}} \pm 0.14$ & $0.36 \pm 0.10$ \\
\hline
\end{tabular}

a,b Means in a column within each main effects with different superscripts differ significantly $(p<0.05) .{ }^{1}$ diet with $15 \%$ crude protein; ${ }^{2}$ diet with $18 \%$ crude protein.

\section{Discussion}

In this study the effects of DLM and MHA-FA supplementation in protein reduced diets on the performance, footpad health and liver health of fattening turkeys were evaluated and the results obtained for the several parameters will be discussed in separate sections.

\subsection{Performance}

There were no complications or mortality observed during the experimental period. On arrival at the experimental facility, female turkeys had an average BW of $4.03 \mathrm{~kg}$ \pm 0.355 and were therefore $15 \%$ below breeder recommendations of $4.73 \mathrm{~kg}$ for B.U.T. 6 females at day 63 [37]. However, the BW achieved at day 98 particularly regarding with standard protein levels exceeded $4640 \mathrm{~g} / \mathrm{bird}$ which was suggested by the breeder as an efficient amount of feed. However, the average BW of turkeys at day 98 was $8.69 \mathrm{~kg} / \mathrm{bird}$ and thus still $8 \%$ below $9.45 \mathrm{~kg}$ as suggested by the breeder. It should be noted that the FCR observed in the present trial ranged between 2.60 and $2.79 \mathrm{~kg} / \mathrm{kg}$ and substantially exceeded the performance goals of the breeding company [37]. Therefore, the experimental feeds were basically well utilised. This is remarkable because specifications for the amino acid levels and applied profile are for heavy female turkeys 98 to 111 days-old, whereas recommendations for 70 to 97 days-old females would be somewhat higher [38].

To reduce nitrogen emissions, a protein reduction in the diets is necessary [16]. This is only possible by balancing in particular the essential amino acids in the feed using free amino acid supplements. In the diets of all experimental groups, the essential amino acids lysine, Met, threonine, tryptophan, arginine, valine and isoleucine were optimised on a digestible amino acid basis to achieve similar levels. This was achieved by individually adding crystalline amino acids (with the exception of MHA-FA which is liquid). Basically, analyses of diets confirmed successful feed production as targeted levels were recovered. However, protein reduction in diets containing $15 \%$ protein was strong ( $3 \%$ points) and showed lower contents of some amino acids than the diets containing $18 \%$ protein. In this context, the lower content of the essential amino acids leucine, histidine and phenylalanine 
and of the semi-essential amino acids serine and glycine in the protein reduced diets has to be noted. This is in line with observations by Lemme et al. [39] who reduced crude protein more moderately by only $1 \%$ point and who achieved a significant reduction in Gly-equivalents (Gly +0.714 * Ser) in the protein-reduced feeds. Moreover, the researchers reported a significantly lower intake of Gly-equivalents at protein reduction.

Despite balancing for six essential amino acids using commercially available products in the experiment, all performance parameters (Tables 4 and 5) were negatively affected by the protein-reduced diets. In contrast to Lemme et al. [39,40], we formulated the experimental feed on a standardised ileal digestible amino acid basis using digestibility coefficient as proposed by Lemme et al. [39-41]. However, these digestibility coefficients were determined with broilers. It has been reported that digestibility coefficients differ between turkeys and broilers which might have interfered with protein reduction, as proportions of ingredients substantially changed [42-44]. Nonetheless, Kluth and Rodehutscord [44] did not report any substantial differences for amino acid digestibility with respect to soybean meal, but Kozslowski et al. [43] suggested differences. Probably more of importance are the amino acids which were not considered for balancing. As mentioned above, the degree of protein reduction was high in this trial, this having tremendous impact on levels of not considered essential amino acids as well as conditionally essential and non-essential amino acids. According to feed analysis, the total levels of lysine, methionine + cysteine, threonine, tryptophane, arginine, valine and isoleucine were $3-7 \%$ lower in low protein diets compared to standard protein, while on a digestible level, they were very similar. However, leucine, histidine and phenylalanine as well as glycine and serine were $20-25 \%$ lower in low protein feeds. While there is no information about requirements for turkeys for these amino acids, it is assumed that one or more of them were below the requirements limiting protein synthesis and, therefore, resulted in lower BW gain and higher PER and FCR. Lemme et al. [40] were not successful in protein reduction as performance dropped in any case. Nevertheless, their research indicated that balancing amino acids beyond lysine, methionine + cysteine, threonine and tryptophan were needed to achieve the same FCR and breast meat deposition as with protein reduction including the entire range of essential amino acids. Indeed, Lemme et al. [6] were able to at least maintain BW gain and FCR when reducing the protein level of commercial type diets by $1 \%$ point and balancing for lysine, methionine + cysteine, threonine, arginine, valine and isoleucine. However, meat deposition was slightly affected. They calculated the intake of essential amino acids as well as glycine-equivalents and concluded that a significantly lower glycine-equivalent intake was responsible for reduced meat deposition. The content of the semi-essential amino acids serine and glycine must be noted. The synthesis of glycine and serine can be limited at a high BW gain intensity, in this case either glycine or serine have to be supplemented to the diet [45]. Dean et al. [45] reported that glycine and serine first had a limiting effect on BW gain and FCR of broilers when protein content of diets was reduced from $22 \%$ to $19 \%$ and all essential amino acids were supplemented. Thus, there is a likelihood that the intake of certain amino acids in this trial was insufficient for maintaining the performance at the level of the standard protein treatments.

With special regard to methionine:cysteine ratio, literature data reporting the optimal methionine:cysteine ratio in poultry diets differ markedly [46]. One important influencing factor is that the metabolic degradation of the indispensable methionine may yield cysteine [47-49]. Consequently, an appropriate amount of cysteine leads to increases the availability of methionine [50]. However, the close metabolic link between methionine and cysteine makes it more difficult to assess both the animals' requirement for total sulfur containing amino acids and the optimal dietary methionine:cysteine [46]. However, Wheeler and Latshaw [51] also found an age-dependent effect on the optimal methionine:cysteine.

Dietary protein reduction significantly reduced water intake. This is an often described effect in the context of protein reduction and is assigned to decreased soybean meal use $[4,16,52,53]$. Soybean meal contributes relatively high levels of potassium to the feed, stimulating water intake [54]. In our trial, inclusion of soybean meal was reduced by $46 \%$. 
In addition, less nitrogen has to be excreted which reduces the water requirement [54]. Assuming $33 \mathrm{~g}$ nitrogen $/ \mathrm{kg}$ weight gain and analysed protein levels of the experimental feeds, average nitrogen depositions of 149, 140,165, and $160 \mathrm{~g} / \mathrm{bird}$ and nitrogen intakes of 314, 295, 390 and $372 \mathrm{~g} /$ bird can be estimated for birds of treatments LP + DLM, LP + MHA-FA, HP + DLM and HP + MHA-FA, respectively, for the experimental period [6]. Accordingly, dietary protein reduction lowered nitrogen excretion by $27 \%$ and thus increased nitrogen utilisation from about $42.6 \%$ to $47.5 \%$. Protein reduction by $1 \%$ point over the entire production cycle reduced N-excretion by $8 \%$, which is a similar magnitude of response when related to $1 \%$ point protein reduction. It is remarkable that reduced water intake due to protein reduction was not reflected in dry matter content of litter in the current trial [6]. Also, Lemme et al. [6] were unable to observe a clear relationship between dietary protein level and litter DM content although they reported markedly improved foot pad health. In the current trial, water intake was not necessarily only influenced by dietary protein per se but also by feed intake. There was a high correlation between water intake and feed intake $(r=0.94)$ and, accordingly, also feed intake was reduced by protein reduction $(p<0.05)$. Still, $\mathrm{W}: \mathrm{F}$ intake ratio would confirm the relationship with soybean meal and related potassium intake as well as with reduced N-excretion. However, the above discussed strong impact on the dietary amino acid profile and respective match with amino acid requirements negatively affected the feed intake. D'Mello [55] described in his review that amino acid imbalances result in reduced or even depressed feed intake in monogastrics including poultry, and the $20-25 \%$ lower levels of those amino acid not considered in feed optimisation may indicate an imbalance. Moreover, Schutte and Pack [56] reported that the increase in methionine levels (i.e., increase in availability and absorption) increased feed intake in broilers. It is well known that The DLM are actively absorbed (transported against a concentration gradient), while MHA-FA is absorbed by the $\mathrm{H}+$ dependent system which is slower than the $\mathrm{Na}+$ system in DLM [57]. According to the literature, the average relative bioavailability of MHA-FA products compared to DLM is approximately $75-80 \%$ on an equimolar basis $[23,58]$. Thus, MHA-FA may be less efficiently absorbed and utilised by birds than DLM and may consequently led to reduce feed intake.

Supplementation of MHA-FA followed the recommendation of Hoehler and Hooge [24] and Hoehler et al. [25]. Accordingly, a relative bioavailability of $65 \%$ is assigned to MHA-FA compared to DLM. This suggests that by replacing MHA-FA with DLM in a weight-toweight ratio of 100:65 in feed, animal performance is not affected. Indeed, the results of the current study basically confirm no detrimental effect of the relatively low inclusion levels of DLM on any performance parameter. Rather the contrary is the case as the BW at the end of the experiments tended to be higher with DLM reflected in the BW gain. Moreover, the apparently lower weight gain can be explained by significantly lower feed intake of MHA-FA fed turkeys, which due to the strong correlation between feed and water intake, was also mirrored in a significantly lower water intake. It is emphasised that neither W:F intake ratio nor PER and FCR were affected by Met sources. Höhler et al. [25] also tested DLM and MHA-FA in a 65:100 ratio at three different supplementation levels in one of the reported trials and described the same growth performance and FCR. Hoehler and Hooge [24] confirmed this observation, as four commercial type trials with $>5000$ turkeys per treatment replacement of MHA-FA with DLM in a 100:65 ratio resulted in the same performance. Agostini et al. [59] fed turkeys over an entire production cycle and while final BW and FCR were not affected by the Met sources supplemented in a 65:100 ratio, they reported a significantly lower breast meat yield in the case of MHA-FA feeding. Lemme and Meyer [38] applying the same experimental design as Agostini et al. [59], also found significantly lower breast meat yield in MHA-FA fed turkeys compared to DLM fed turkeys. When correcting for mortality, FCR tended to be higher with MHA-FA ( $p=0.54)$ in the latter study. When summarising literature findings and the current study, it can be concluded that replacing MHA-FA with DLM in turkey feed at a weight-to-weight ratio of 100:65 results in the same performance. Few results even indicated a slight advantage for DLM. There is quite a lot research on these Met sources with respect to physiology 
and metabolism providing evidence for the lower bioavailability of MHA-FA compared to DLM. Research performed by Maenz and Engele-Schaan [57], Drew et al. [60] and Malik et al. [61] suggested that a substantial portion of ingested MHA-FA is degraded by intestinal microbes and thus, not available to the host. DLM is absorbed by sodiumdriven transport with high affinity of the transporters to DLM and a relatively high velocity, whereas MHA-FA is absorbed like short chain fatty acids with proton-driven transporters with relatively low affinity to MHA-FA and relatively low velocity [57]. Moreover, the latter study suggests that diffusion through tight junctions of the intestinal wall does not play a role. Finally, absorption studies by Mitchell and Lemme [62] suggest that especially the short chains of liquid MHA-FA are poorly absorbed. This finding is confirmed by Rhone Poulenc [63] and Van Weerden et al. [64] who conducted simultaneous dose-response studies with DLM, MHA-FA and only short MHA-FA chains, consistently reporting a lower relative bioavailability of MHA-FA oligomers compared to the commercial MHA-FA product which contains about $65 \%$ monomers, $23 \%$ monomers and $12 \%$ water.

\subsection{Footpad Health}

Impaired footpad health is often related to increased water intake, increased water excretion and, as a consequence, increased litter moisture. Indeed, we could not find a clear effect of protein reduction on litter moisture nor could Lemme et al. [6], but Lemme et al. [6] found a clear improvement in footpad health, as the average lesion score could be reduced especially by increased proportions of grade 0 and grade 1 scores. The same was observed in the current study, as footpad scoring numbers were significantly reduced with protein reduction. This effect was measurable after four weeks of feeding the diets. In their review on low protein nutrition of broilers, Greenhalgh et al. [54] clearly indicated the relationship with improved footpad health. At day 98, the evaluation of the influence of the Met source showed tendentiously lower FPD scores for DLM compared to MHA-FA $(p<0.10)$. This is in line with the positive effect of Met supplementation on footpad health which has been described many times $[10,12,13,65,66]$. Deficiency in Met intake has a significant negative impact on animals such as growth inhibition via interruption in protein synthesis (i.e., affect skin structure), the induction of metabolic disorder, and the reduction of disease defensive potential [67]. Abd El-Wahab et al. [10] found that at almost identical litter DM contents (measured weekly), the young turkeys fed high level of Met in diet had lower FPD scores than those fed diet with low Met content. It means that level of dietary Met plays an important role for health of skin rather than moisture content in the litter. Thus, it seems that Met has a specific function regards foot pad health (as known for skin and feathers) as mentioned by Abd El-Wahab et al. [14] via protein synthesis and continuous production of keratin. Consequently, low availability of Met could affect protein synthesis negatively and affect skin of foot pad.

Chavez and Kratzer [13] compared the influence of DLM and MHA-FA on the footpad health of white fattening turkeys. They found that supplementing a basal diet with $4.00 \mathrm{~g}$ $\mathrm{DLM} / \mathrm{kg}$ diet resulted in an improvement in footpad health that was not achieved to the same extent by supplementing $4.03 \mathrm{~g}$ of MHA-FA/ $\mathrm{kg}$ diet. When interpreting the studies of Chavez and Kratzer [13], it must be noted that the comparing $4 \mathrm{~g}$ DLM with $4.03 \mathrm{~g}$ MHA-FA, an equivalence of both substances was assumed regarding the biological activity, whereas the authors of other studies assumed a lower biological activity of MHA-FA [10]. The tendentiously lower FPD scores of the animals whose diets contained DLM compared to those with equivalent supplementation of MHA-FA (based on 65\% biological activity) corresponds to the observations of Chavez and Kratzer [13] and Abd El Wahab et al. [68].

\subsection{Liver}

The significantly higher relative liver weight of the protein-reduced groups has to be seen in context to the lower BW of the animals which were fed low protein diets. Nonetheless, the livers of the animals in low protein groups still had numerically higher crude fat content of the livers than those in groups with $18 \%$ protein in the diet. Here the 
$7 \%$ higher starch content of protein-reduced diets must be noted, since a high carbohydrate content of a diet increases the de novo lipogenesis in the liver [69]. As a consequence of enhanced de novo lipo-genesis in the liver of birds fed the low protein diets [70,71], birds are expected to have increased liver weights and deposit more abdominal fat due to increased energy:protein ratio. Hidalgo et al. [72] also reported no differences in carcass yield, breast meat yield, and abdominal fat pad in broilers fed low-protein diets with a constant energy:protein ratio. Chrystal et al. [5] summarised 19 broiler feeding studies and reported that body fat deposition was increased by $36 \%$ on average with an average protein reduction of $5.5 \%$ points. They as well as Liu et al. [53] related this effect to the shift towards a higher starch content with protein reduction and further suggested related changing digestion dynamics of starch and protein in broilers. An increase in the fat content of the liver when "protein compounds" are replaced by high-starch "energy compounds" also corresponds to the observations of Zhang et al. [73]. They compared the use of soybeans, corn starch and lard in isoenergetic and isoproteic diets in laying hens and found a significant increase in fat content of livers when corn starch (fat content liver: $11.8 \%$ ) and lard (fat content liver: $10.2 \%$ ) were used compared to soybeans (fat content liver: $8.2 \%)$.

\subsection{Oxidative Stress}

Liver is a major organ attacked by reactive oxygen species and parenchymal cells are primary cells subjected to oxidative stress-induced injury in the liver. DLM may be more effectively used in glutathione synthesis compared to MHA-FA, which can potentially explain the higher TAC observed in the present study. The influence of various Met sources on parameters of oxidative capacity has previously been discussed in literature. Zeitz et al. [74] and Zhang et al. [75] studied the effects of the two Met sources on various parameters related to oxidative stress in broilers. Compared to deficient methionine + cysteine supply, supplementation of either Met source improved antioxidant status but no differences between products were observed. Liu et al. [76] tested DLM and MHA-FA under heat stress conditions and reported some effects and interactions of Met sources. Accordingly, DLM fed broilers in the grower phase had greater muscle GSH and hepatic unsaturated fatty acid concentrations than MHA-FA fed birds. Nonetheless, across all measured tissues, parameters and ages, only few data sets were affected by Met sources. Wang et al. [77] concluded from their research on broilers that DLM could be effectively used in glutathione synthesis to exert antioxidant functions, whereas MHA-FA favoured S-adenosylmethionine synthesis. The reduced availability of glutathione in the MHA-FA fed broilers may have led to an increased sense of oxidative stress, which is supported by the observation that antioxidant-related gene expression was increased in this treatment.

\section{Conclusions}

In light of the conducted experiment, it is possible to conclude that supplementing six essential amino acids proved insufficient to compensate the strong protein reduction in the diet, which led to a significantly lower performance despite the increase in footpad health. Additionally, the response observed regarding the crude protein reduction is independent of the Met sources. Regarding the Met sources, it was concluded that replacing MHA-FA with 65 parts of DLM in feed does not compromise performance and additionally has advantages for the antioxidant capacity of the liver parenchyma.

Author Contributions: Conceptualisation, J.B.L. and C.V.; Data curation, A.A.E.-W., J.B.L. and C.V.; Formal analysis, J.B.L. and A.A.E.-W.; Funding acquisition, J.C.d.P.D., A.L. and C.V.; Investigation, J.B.L., R.B. and C.V.; Methodology, J.B.L., A.A.E.-W., M.L. and R.B.; Project administration, C.V.; Resources, C.V.; Supervision, C.V.; Validation, C.V.; Visualisation, J.B.L., A.A.E.-W., R.B. and C.V.; Writing-Original Draft Preparation, J.B.L., A.A.E.-W. and C.V.; Writing-Review and Editing, J.B.L., A.A.E.-W., J.C.d.P.D., A.L., M.L., R.B. and C.V. All authors have read and agreed to the published version of the manuscript. 
Funding: This study was funded by Evonik Operations GmbH, Essen, Germany. The role of the funding body was merely financial for purchasing the materials and analyzing the data for the trials at the Institute for Animal Nutrition, University of Veterinary Medicine Hannover, Foundation, Germany. It did not have any role in the collection, interpretation, analysis or writing of the data. This publication was supported by Deutsche Forschungsgemeinschaft and University of Veterinary Medicine Hannover, Foundation within the funding programme Open Access Publishing.

Institutional Review Board Statement: The experiment was carried out in accordance with German regulations. The Ethics Committee of Lower Saxony for Care and Use of Laboratory Animals (LAVES) approved the experiment in accordance with $\S 4$, paragraph 3 of the Animal Protection Act (reference number: 33.8-42502-05-18A313).

Informed Consent Statement: Not applicable.

Data Availability Statement: The original contributions generated for the study are included in the article, further inquiries of which can be directed to the corresponding author.

Acknowledgments: We would like to thank Frances Sherwood-Brock for proof-reading the manuscript to ensure correct English.

Conflicts of Interest: J.C.P.D. and A.L. are employees of Evonik Operations GmbH. They had no role in the collection, analyses or interpretation of data nor in the writing of the manuscript or in the decision to publish the results. The manuscript has not been previously published.

\section{References}

1. Dawkins, M.S. Animal welfare and efficient farming: Is conflict inevitable? Anim. Prod. Sci. 2016, 57, 201-208. [CrossRef]

2. Kapell, D.; Hocking, P.; Glover, P.; Kremer, V.; Avendaño, S. Genetic basis of leg health and its relationship with body weight in purebred turkey lines. Poult. Sci. 2017, 96, 1553-1562. [CrossRef]

3. Vieira, S.L.; Stefanello, C.; Cemin, H.S. Lowering the dietary protein levels by the use of synthetic amino acids and the use of a mono component protease. Anim. Feed. Sci. Technol. 2016, 221, 262-266. [CrossRef]

4. Selle, P.H.; De Paula Dorigam, J.C.; Lemme, A.; Chrystal, P.V.; Liu, S.Y. Synthetic and Crystalline Amino Acids: Alternatives to Soybean Meal in Chicken-Meat Production. Animals 2020, 10, 729. [CrossRef]

5. Chrystal, P.V.; Greenhalgh, S.; Selle, P.H.; Liu, S.Y. Facilitating the acceptance of tangibly reduced-crude protein diets for chicken-meat production. Anim. Nutr. 2020, 6, 247-257. [CrossRef] [PubMed]

6. Lemme, A.; Naranjo, V.; De Paula Dorigam, J.C. Utilization of Methionine Sources for Growth and Met+Cys Deposition in Broilers. Animals 2020, 10, 2240. [CrossRef]

7. Rychen, G.; Aquilina, G.; Azimonti, G.; Bampidis, V.; De Lourdes Bastos, M.; Bories, G.; Chesson, A.; Cocconcelli, P.S.; Flachowsky, G.; Gropp, J.; et al. Safety and efficacy of hydroxy analogue of methionine and its calcium salt (ADRY $+{ }^{\circledR}$ ) for all animal species. EFSA J. 2018, 16, e05198. [CrossRef]

8. Gazdzinski, P.; Squires, E.J.; Julian, R.J. Hepatic lipidosis in turkeys. Avian Dis. 1994, 38, 379-384. [CrossRef]

9. Popp, C.; Hauck, R.; Vahlenkamp, T.W.; Lüschow, D.; Kershaw, O.; Hoferer, M.; Hafez, H.M. Liver pathology associated with increased mortality in turkey breeder and meat turkey flocks. Avian Dis. 2014, 58, 474-481. [CrossRef]

10. Abd El-Wahab, A.; Kölln, M.; Kamphues, J. Is there a specific role of dietary methionine or its source regarding foot pad health in fattening turkeys? In Proceedings of the 10th Hafez International Symposium on Turkey Diseases, Berlin, Germany, 5-7 June 2014; Mensch und Buch Verlag: Berlin, Germany, 2014; pp. 22-32.

11. Shen, Y.B.; Ferket, P.; Park, I.; Malheiros, R.D.; Kim, S.W. Effects of feed grade L-methionine on intestinal redox status, intestinal development, and growth performance of young chickens compared with conventional dl-methionine. J. Anim. Sci. 2015, 93, 2977-2986. [CrossRef] [PubMed]

12. Chavez, E.; Kratzer, F.H. Prevention of foot pad dermatitis in poults with Methionine. Poult. Sci. 1972, 51, 1545-1548. [CrossRef]

13. Chavez, E.; Kratzer, F.H. Effect of diet on foot pad dermatitis in poults. Poult. Sci. 1974, 53, 755-760. [CrossRef]

14. Abd El-Wahab, A.; Ahmed, M.; Ibrahim, T. Impact of dietary methionine levels and sources on performance and health of foot pad in broilers. Asian J. Anim. Vet. Adv. 2016, 11, 357-362. [CrossRef]

15. Li, C.; Lesuisse, J.; Schallier, S.; Climaco, W.; Wang, Y.; Bautil, A.; Everaert, N.; Buyse, J. The effects of a reduced balanced protein diet on litter moisture, pododermatitis and feather condition of female broiler breeders over three generations. Anim. Int. J. Anim. Biosci. 2018, 12, 1493-1500. [CrossRef]

16. Lemme, A.; Hiller, P.; Klahsen, M.; Taube, V.; Stegemann, J.; Simon, I. Reduction of dietary protein in broiler diets not only reduces n-emissions but is also accompanied by several further benefits. J. Appl. Poult. Res. 2019, 28, 867-880. [CrossRef]

17. Kidd, M.T.; Maynard, C.W.; Mullenix, G.J. Progress of amino acid nutrition for diet protein reduction in poultry. J. Anim. Sci. Biotechnol. 2021, 12, 45. [CrossRef] [PubMed] 
18. Visscher, C.; Middendorf, L.; Gunther, R.; Engels, A.; Leibfacher, C.; Mohle, H.; Dungelhoef, K.; Weier, S.; Haider, W.; Radko, D. Fat content, fatty acid pattern and iron content in livers of turkeys with hepatic lipidosis. Lipids Health Dis. 2017, 16, 98. [CrossRef] [PubMed]

19. Azis, R. Hepatic lipidosis in turkeys. World Poult. 2008, 24, 28-29.

20. Jariyahatthakij, P.; Chomtee, B.; Poeikhampha, T.; Loongyai, W.; Bunchasak, C. Effects of adding methionine in low-protein diet and subsequently fed low-energy diet on productive performance, blood chemical profile, and lipid metabolism-related gene expression of broiler chickens. Poult. Sci. 2018, 97, 2021-2033. [CrossRef]

21. Jansman, A.J.M.; Kan, C.A.; Wiebenga, J. Comparison of the Biological Efficacy of DL-Methionine and Hydroxy4-Methylthiobutanoic Acid (HMB) in Pigs and Poultry; Animal Sciences Group: London, UK, 2003.

22. Vazquez-Anon, M.; Kratzer, D.; Yi, I.G.; Knight, C.D.; Gonzalez-Esquerra, R. A multiple regression model approach to contrast the performance of 2-hydroxy-4-methylthio butanoic acid and DL-methionine supplementation tested in broiler experiments and reported in the literature. Poult. Sci. 2006, 85, 693-705. [CrossRef] [PubMed]

23. Sauer, N.; Emrich, K.; Piepho, H.P.; Lemme, A.; Redshaw, M.S.; Mosenthin, R. Meta-analysis of the relative efficiency of methionine-hydroxy-analogue-free-acid compared with DL-methionine in broilers using nonlinear mixed models. Poult. Sci. 2008, 87, 2023-2031. [CrossRef] [PubMed]

24. Hoehler, D.; Hooge, D.M. Relative Effectiveness of Methionine Sources in Turkeys-Scientific and New Commercial Data. Int. J. Poult. Sci. 2003, 2, 361-366.

25. Hoehler, D.; Lemme, A.; Jensen, S.K.; Vieira, S.L. Relative Effectiveness of Methionine Sources in Diets for Broiler Chickens. J. Appl. Poult. Res. 2005, 14, 679-693. [CrossRef]

26. Lemme, A.; Hoehler, D.; Brennan, J.J.; Mannion§, P.F. Relative effectiveness of methionine hydroxy analog compared to DLmethionine in broiler chickens. Poult. Sci. 2003, 81, 838-845. [CrossRef] [PubMed]

27. Agostini, P.S.; Dalibard, P.; Mercier, Y.; Van Der Aar, P.; Van der Klis, J.D. Comparison of methionine sources around requirement levels using a methionine efficacy method in 0 to 28 day old broilers. Poult. Sci. 2016, 95, 560-569. [CrossRef]

28. Jankowski, J.; Ognik, K.; Kubi'nska, M.; Czech, A.; Ju'skiewicz, J.; Zdu'nczyk, Z. The effect of DL-, L-isomers and DL-hydroxy analog administered at 2 levels as dietary sources of methionine on the metabolic and antioxidant parameters and growth performance of turkeys. Poult. Sci. 2017, 96, 3229-3238. [CrossRef] [PubMed]

29. Aviagen Turkeys. Feeding Guidelines for Nicholas and B.U.T. Heavy Lines; Aviagen Turkeys: Tattenhall, UK, 2018.

30. Llames, C.R.; Fontaine, J. Determination of Amino Acids in Feeds: Collaborative Study. J. AOAC Int. 2020, 77, 1362-1402. [CrossRef]

31. Directive, C. Establishing community methods for the determination of amino acids, crude oils and fats, and olaquindox in feeding stuff and amending directive 71/393/EEC, annex part a. Determination of amino acids. Off. J. Eur. Communities L 1998, $257,14-23$.

32. VDLUFA. Bestimmung von DL-2-Hydroxy-4-methyl-mercapto-buttersäure nach Hydrolyse (Gesamt MHAR). In Methode 4.11.4 Methodenbuch. Band III. Die Chemische Untersuchung von Futtermitteln, 4th Supplement; VDLUFA-Verlag: Darmstadt, Germany, 1997.

33. Ullrich, C.; Langeheine, M.; Brehm, R.; Taube, V.; Rosillo Galera, M.; Rohn, K.; Popp, J.; Visscher, C. Influence of different methionine sources on performance and slaughter characteristics of broilers. Animals 2019, 9, 984. [CrossRef] [PubMed]

34. Mayne, R.; Else, R.; Hocking, P. High litter moisture alone is sufficient to cause footpad dermatitis in growing turkeys. Br. Poult. Sci. 2007, 48, 538-545. [CrossRef] [PubMed]

35. Middendorf, L.; Radko, D.; Dungelhoef, K.; Sieverding, E.; Windhaus, H.; Mischok, D.; Visscher, C. Amino acid pattern in the liver and blood of fattening turkeys suffering from hepatic lipidosis. Poult. Sci. 2019, 98, 3950-3962. [CrossRef]

36. Naumann, C.; Bassler, R. Methoden der landwirtschaftlichen Forschungs-und Untersuchungsanstalt, Biochemische Untersuchung von Futtermitteln. In Methodenbuch, Band III. Die Chemische Untersuchng von Futtermitteln (Einschließlich der Achten Ergänzungen); VDLUFA Verlag: Darmstadt, Germany, 2012.

37. Aviagen Turkeys. B.U.T. 6: Mastleistungsziele. Zugriff. 5 September 2019. Available online: http:/ / www.aviagenturkeys.com/ de-de/?redirectedfrom=en-us (accessed on 1 August 2021).

38. Lemme, A. Turkey production: Toward better welfare and health. In Proceedings of the 5th Symposium Turkey Production, Berlin, Germany, 28-30 May 2009; Volume 5.

39. Lemme, A. Turkey Times. In Proceedings of the 14th Turkey Science and Production Conference, Chester, UK, 4-6 March 2020; pp. $79-86$.

40. Lemme, A.; Frackenpohl, U.; Petri, A.; Meyer, H. Effects of Reduced Dietary Protein Concentrations with Amino Acid Supplementation on Performance and Carcass Quality in Turkey Toms 14 to 140 Days of Age. Int. J. Poult. Sci. 2004, 3, 391-399. [CrossRef]

41. Lemme, A.; Ravindran, V.; Bryden, W.L. Ileal digestibility of amino acids in feed ingredients for broilers. World's Poult. Sci. J. 2004, 60, 423-438. [CrossRef]

42. Kozłowski, K.; Helmbrecht, A.; Jankowski1, A.L.J.; Kluge, H.; Jeroch, H. Standardized ileal amino acid digestibility (SIAAD) of wheat DDGS in male growing turkeys. Arch. Geflugelkd. 2012, 76, 136-139.

43. Kozłowski, K.; Helmbrecht, A.; Lemme, A.; Jankowski, J.; Jeroch, H. Standardized ileal digestibility of amino acids from high-protein feedstuffs for growing turkeys-A preliminary study. Arch. Geflügelk. 2011, 75, 185-190. 
44. Kluth, H.; Rodehutscord, M. Comparison of Amino Acid Digestibility in Broiler Chickens, Turkeys, and Pekin Ducks. Poult. Sci. 2006, 85, 1953-1960. [CrossRef]

45. Dean, D.W.; Bidner, T.D.; Southern, L.L. Glycine supplementation to low protein, amino acid-supplemented diets supports optimal performance of broiler chicks. Poult. Sci. 2006, 85, 288-296. [CrossRef] [PubMed]

46. Brede, A.; Wecke, C.; Liebert, F. Does the Optimal Dietary Methionine to Cysteine Ratio in Diets for Growing Chickens Respond to High Inclusion Rates of Insect Meal from Hermetia illucens? Animals 2018, 8, 187. [CrossRef]

47. Stipanuk, M.H. Metabolism of sulfur-containing amino acids. Annu. Rev. Nutr. 1986, 6, 179-209. [CrossRef]

48. Stipanuk, M.H. Sulfur amino acid metabolism: Pathways for production and removal of homocysteine and cysteine. Annu. Rev. Nutr. 2004, 24, 539-577. [CrossRef]

49. Brosnan, J.T.; Brosnan, M.E. The sulfur-containing amino acids: An overview. J. Nutr. 2006, 136, 1636-1640. [CrossRef] [PubMed]

50. Bunchasak, C.; Kimura, G.; Tanaka, K.; Ohtani, S.; Collado, C.M. The Effect of Supplementing Cystine on the Growth Performance and Liver Lipid and Phospholipid Contents of Broiler Chicks. Jpn. Poult. Sci. 1998, 35, 60-66. [CrossRef]

51. Wheeler, K.; Latshaw, J. Sulfur amino acid requirements and interactions in broilers during two growth periods. Poult. Sci. 1981, 60, 228-236. [CrossRef] [PubMed]

52. Francesch, M.; Brufau, J. Nutritional factors affecting excreta/litter moisture and quality. World's Poult. Sci. J. 2004, 60, 64-75. [CrossRef]

53. Liu, S.Y.; Macelline, S.P.; Chrystal, P.V.; Selle, P.H. Progress towards reduced-crude protein diets for broiler chickens and sustainable chicken-meat production. J. Anim. Sci. Biotechnol. 2021, 12, 20. [CrossRef] [PubMed]

54. Greenhalgh, S.; Chrystal, P.V.; Selle, P.H.; Liu, S.Y. Reduced-crude protein diets in chicken-meat production: Justification for an imperative. World's Poult. Sci. J. 2020, 76, 537-548. [CrossRef]

55. D'mello, J.P.F. Adverse Effects of Amino Acids. Amino Acids Anim. Nutr. 2003, 2, 125-142.

56. Schutte, J.B.; Pack, M. Effects of dietary sulphur-containing amino acids on performance and breast meat deposition of broiler chicks during the growing and finishing phases. Br. Poult. Sci. 1995, 36, 747-762. [CrossRef] [PubMed]

57. Maenz, D.D.; Engele-Schaan, M. Methionine and 2-Hydroxy-4-Methylthioobutanoic Acid are transported by distinct $\mathrm{Na}^{+}{ }_{-}$ dependent and $\mathrm{H}^{+}$-dependent systems in the brush border membrane of the chick intestinal epithelium. J. Nutr. 1996, 126, 529-536. [CrossRef] [PubMed]

58. Baker, D.H. Comparative species utilization and toxicity of sulfur amino acids. J. Nutr. 2006, 136, 1670S-1675S. [CrossRef]

59. Agostini, P.S.; Aar, P.v.d.; Naranjo, V.D.; Lemme, A. Effect of methionine source at marginal and adequate methionine levels in turkeys. In Proceedings of the 21st European Symposium on Poultry Nutrition, Salou/Vila-seca, Spain, 8-11 May 2017.

60. Drew, M.D.; Syed, N.A.; Goldade, B.G.; Laarveld, B.; Kessel, A.G.V. Effects of Dietary Protein Source and Level on Intestinal Populations of Clostridium perfringens in Broiler Chickens. Poult. Sci. 2004, 83, 414-420. [CrossRef] [PubMed]

61. Malik, G.; Hoehler, D.; Rademacher, M.; Drew, M.D.; Kessel1, A.G.V. Apparent absorption of methionine and 2-hydroxy4methylthiobutanoic acid from gastrointestinal tract of conventional and gnotobiotic pigs. Animal 2009, 3, 1378-1386. [CrossRef] [PubMed]

62. Mitchell, M.A.; Lemme, A. Examination of the Composition of the Luminal Fluid in the Small Intestine of Broilers and Absorption of Amino Acids under Various Ambient Temperatures Measured In Vivo. Int. J. Poult. Sci. 2008, 7, $223-233$.

63. Uzu, G. Comparison of nutritional efficacy of DL-methionine and its hydroxy analog free acid in broilers. Rhône-Poulenc Feed Addit. Dev. 1983, 125, 33.

64. Van Weerden, E.J.; Schutte, J.B.; Bertram, H.L. Utilization of the polymers of methionine hydroxy analogue free acid (MHA-FA) in broiler chicks. Archiv. Geflügelkunde 1992, 56, 63-68.

65. Murillo, M.G.; Jensen, L.S. Sulfur amino acid requirement and foot pad dermatitis in turkey poults. Poult. Sci. 1976, 55, 554-562. [CrossRef] [PubMed]

66. Abd El-Wahab, A.; Aziza, A.; El-Adl, M. Impact of dietary excess methionine and lysine with or without addition of L-carnitine on performance, blood lipid profile and litter quality in broilers. Asian J. Anim. Vet. Adv. 2015, 10, 191-202. [CrossRef]

67. Bunchasak, C. Role of dietary methionine in poultry production. J. Poult. Sci. 2009, 46, 169-179. [CrossRef]

68. Abd El-Wahab, A.; Visscher, C.; Ratert, C.; Kolln, M.; Diephaus, D.; Beineke, A.; Kamphues, J. Outcome of an Experimental Study in Growing Turkeys Suspected of Having a Diet Related, Uncommon and Uncoordinated Gait. Vet. Sci. 2017, 4, 49. [CrossRef]

69. Parks, E.J.; Krauss, R.M.; Christiansen, M.P.; Neese, R.A.; Hellerstein, M.K. Effects of a low-fat, high-carbohydrate diet on VLDL-triglyceride assembly, production, and clearance. J. Clin. Invest. 1999, 104, 1087-1096. [CrossRef]

70. Rosebrough, R.; Steele, N. Energy and protein relationships in the broiler: 1. Effect of protein levels and feeding regimens on growth, body composition, and In Vitro lipogenesis of broiler chicks. Poult. Sci. 1985, 64, 119-126. [CrossRef] [PubMed]

71. Swennen, Q.; Janssens, G.; Collin, A.; Le Bihan-Duval, E.; Verbeke, K.; Decuypere, E.; Buyse, J. Diet-induced thermogenesis and glucose oxidation in broiler chickens: Influence of genotype and diet composition. Poult. Sci. 2006, 85, 731-742. [CrossRef]

72. Hidalgo, M.; Dozier, W., III; Davis, A.; Gordon, R. Live performance and meat yield responses of broilers to progressive concentrations of dietary energy maintained at a constant metabolizable energy-to-crude protein ratio. J. Appl. Poult. Res. 2004, 13, 319-327. [CrossRef]

73. Zhang, J.W.; Chen, D.W.; Yu, B.; Wang, Y.M. Effect of dietary energy source on deposition and fatty acid synthesis in the liver of the laying hen. Br. Poult. Sci. 2011, 52, 704-710. [CrossRef] [PubMed] 
74. Zeitz, J.O.; Mohrmann, S.; Fehse, L.; Most, E.; Helmbrecht, A.; Saremi, B.; Eder, K. Tissue and plasma antioxidant status in response to dietary methionine concentration and source in broilers. J. Anim. Physiol. Anim. Nutr. 2018, 102, 999-1011. [CrossRef]

75. Zhang, S.; Gilbert, E.R.; Saremi, B.; Wong, E.A. Supplemental methionine sources have a neutral impact on oxidative status in broiler chickens. J. Anim. Physiol. Anim. Nutr. 2018, 102, 1274-1283. [CrossRef]

76. Liu, G.; Magnuson, A.D.; Sun, T.; Tolba, S.A.; Starkey, C.; Whelan, R.; Lei, X.G. Supplemental methionine exerted chemical form-dependent effects on antioxidant status, inflammation-related gene expression, and fatty acid profiles of broiler chicks raised at high ambient temperature. J. Anim. Sci. 2019, 97, 4883-4894. [CrossRef] [PubMed]

77. Wang, Y.; Yin, X.; Yin, D.; Lei, Z.; Mahmood, T.; Yuan, J. Antioxidant response and bioavailability of methionine hydroxy analog relative to DL-methionine in broiler chickens. Anim. Nutr. 2019, 5, 241-247. [CrossRef] 